\title{
Effects of dietary acetaminophen and vitamin $C$ supplements on stress and inflammatory responses in Korean native cattle vaccinated with foot-and- mouth disease vaccine - a short communication
}

\author{
Eun-Kee Park ${ }^{1}$, Song-Ee Son ${ }^{2}$, Suk Kim² ${ }^{2}$, and Hu-Jang Lee ${ }^{2 *}$ \\ ${ }^{1}$ Department of Medical Humanities and Social Medicine, College of Medicine, Kosin University, Busan, \\ South Korea \\ ${ }_{2}^{2}$ Institute of Animal Medicine, College of Veterinary Medicine, Gyeongsang National University, Jinju, South Korea
}

PARK, E-K., S-E. SON, S. KIM, H-J. LEE: Effects of dietary acetaminophen and vitamin C supplements on stress and inflammatory responses in Korean native cattle vaccinated with foot-and-mouth disease vaccine - a short communication. Vet. arhiv 89, 87-92, 2019.

\section{ABSTRACT}

This study evaluated the effect of a combination of acetaminophen and vitamin C (CAV) for reduction of stress and inflammatory responses in calves vaccinated with foot-and-mouth disease (FMD) vaccine. Twenty-five calves were divided into five groups of 5 calves. The negative control was non-vaccination and non-drug treatment. The positive control, and experimental groups I, II and III were vaccinated with FMD vaccine and treated with CAV at concentrations of $0.0,0.5,1.0$ and $2.0 \mathrm{~kg} /$ ton feed, respectively, for five consecutive days post-vaccination. On day 5 post-treatment, serum cortisols and tumor necrosis factor- $\alpha$ (TNF- $\alpha$ ) were significantly decreased in all treatment groups compared with the positive control $(\mathrm{P}<0.05)$. However, there was no significant difference in serum cortisol and TNF- $\alpha$ levels between experimental groups I and II and the negative control. The results from this study suggest that CAV may be a useful drug for control of the stress and inflammation caused by FMD vaccination in calves.

Key words: foot and mouth disease vaccination; serum cortisol; serum TNF- $\alpha$; acetaminophen; vitamin C; cattle

\section{Introduction}

Foot and mouth disease (FMD) is a highly contagious and fatal viral disease in clovenhooved animals, characterized by vesicles in the mouth, tongue, hoofs, and nipples and increases in body temperature and appetite loss (LEE et al., 2013). FMD is one of the most important livestock diseases in the world in terms of economic impact. The economic importance of the disease is not only due to the ability of the disease to cause loss

of production but also the restriction of trade in animals both locally and internationally (LEE et al., 2016). The causal agent of the FMD virus (FMDV) (family Picornaviridae, genus Aphthovirus) is a positive-sense, non-enveloped, single-stranded RNA virus, and FMDV has 7 immunologically distinct serotypes (A, O, Asia1, C, and South African Territories (SAT) types 1, 2, 3) (JAMAL and BELSHAM, 2013).

*Corresponding author:

Hu-Jang Lee, PhD, College of Veterinary Medicine, Gyeongsang National University, 501 Jinju-dae-ro, Jinju 660-701, Korea, Phone: +82 55 772 2352; Fax: +82-55-772-2308; E-mail: hujang@gnu.ac.kr 
Up to now, several FMD outbreaks have occurred in South Korea since 2000, in 2000, 2002, 2010-2011 and 2014-2015 (LEE et al., 2013; LEE et al., 2016). Since the FMD outbreak of 2010-2011, a national blanket vaccination policy has been enforced for ruminants and pigs as a sustainable preventive measure, and the routine vaccination program is still a central control tool against FMDV infection, although this program is somewhat controversial (LEE et al., 2016).

Considering FMD outbreaks in surrounding countries, typical vaccinations were started in September 2011 in the Republic of Korea using trivalent FMD vaccines (types $\mathrm{O}, \mathrm{A}$, and Asia1) (LEE et al., 2013). The trivalent FMD vaccine consists of inactivated viruses with double oil-based emulsion, and includes structural proteins of FMD viruses (O1 Manisa + A Malaysia + Asia 1 Shamir serotypes) (LEE et al., 2016). Although multivalent FMD vaccines reduced the large FMD outbreak, a single-dose injection of the trivalent FMD vaccine in pigs has many problems, including poor humoral immune induction and a short period of immune duration compared to that induced by natural FMDV infection (LEE et al., 2016). Also, the vaccination practice can cause stress to the animals due to the act of animal-handling, the injection, or a possible inflammatory response, and some adverse effects resulting from the vaccination have been reported. Growth reduction, disturbance of pregnancy, and a drop in milk production following vaccination have been observed in various species (YERUHAM et al., 2001).

Immune responses of animals to FMD vaccines have been extensively investigated (LEE et al., 2014). However, there are few published reports on the control of stress and inflammatory responses in cattle after FMD vaccination. Therefore, the present study evaluated the reductive potential of a combination of acetaminophen and vitamin $\mathrm{C}$ $(\mathrm{CAV})$ on stress and inflammatory responses in Korean native calves post-FMD vaccination.

\section{Materials and methods}

Drug. The drug (AD-Anyless Powder ${ }^{\circledR}$ ) was purchased from ADbiotech Co. Ltd. (Chuncheon,
South Korea). This medication contains $20 \%$ of acetaminophen and $10 \%$ of vitamin C.

Experimental animals. All the procedures with animals were done in compliance with the legislation on animal welfare (Animal Protection Law (Official Gazette 13023)) and were approved by the Institutional Animal Care and Use Committee of Gyeongsang National University, Jinju (GNU180112-A0004). The study was conducted on the livestock farm of Gyeongsang National University located in the Jinju area in Gyeongsang province, South Korea. Twenty-five 9-month-old Korean native calves without any history of FMD vaccination were selected and randomly divided into five groups of 5 calves. Five experimental groups consisted of negative control, positive control and three experimental groups I, II and III.

Treatment. The negative control was a nonvaccinated group and supplied with the usual feed. Also, the positive control, and experimental groups I, II and III were vaccinated with FMD vaccine and administered with the drug at the concentrations of $0.0,0.5,1.0$ and $2.0 \mathrm{~kg}$ per ton feed, respectively, for 5 consecutive days post-vaccination. The FMD vaccine was an inactivated trivalent FMDV vaccine (PRO-VAC ${ }^{\circledR}$ FMD) purchased from Komipharm International Co., Ltd. (Siheung, South Korea). This vaccine was formulated as a double oil-based emulsion (DOE) adjuvant with at least six 50\% protective doses $\left(\mathrm{PD}_{50}\right)$ of inactivated trivalent FMDVs (O1 Manisa + A Malaysia + Asia 1 Shamir serotypes).

Blood sampling and analysis. On the $1^{\text {st }}, 3^{\text {rd }}$ and $5^{\text {th }}$ days after administration of the drug, blood samples were collected into heparinized vacutainer tubes from the tail vein of all calves. All blood samples were centrifuged at $2,000 \times \mathrm{g}$ for $10 \mathrm{~min}$ to separate the serum. According to the manual procedures, cortisol and tumor necrosis factoralpha (TNF- $\alpha$ ) concentrations in the serum were analyzed with a bovine cortisol ELISA kit and TNF- $\alpha$ ELISA kit purchased from Cusabio Biotech Co. Ltd. (Baltimore, Maryland, USA).

Statistical analysis. All results were presented as the mean \pm standard deviation (SD). All analyses were performed using the SPSS statistical software 
package (version 18.0, SPSS Inst., Inc., USA). Data were analyzed using one-way analysis of variance (ANOVA), followed by the student's two-tailed $\mathrm{t}$-test. The value of $\mathrm{P}<0.05$ was used as the criterion for statistical significance.

\section{Results and discussion}

Changes in serum cortisol concentrations are presented in Fig. 1.

On day 1 after treatment, cortisol concentrations were significantly increased in experimental groups I and II compared with the negative control $(\mathrm{P}<0.05)$, and they were considerably decreased in experimental group III compared with the positive control $(\mathrm{P}<0.05)$. However, there were no significant differences in cortisol levels between experimental group III and the negative control. On day 3 post-treatment, cortisol concentrations were significantly increased in experimental groups I and II compared with the negative control $(\mathrm{P}<0.05)$, but they were significantly decreased in experimental groups II and III compared with the positive control $(\mathrm{P}<0.05)$. Also, cortisol concentrations in experimental group III were not significantly different compared to those in the negative control. On day 5 post-treatment, cortisol concentrations in experimental groups I and II were significantly increased compared to the negative control $(\mathrm{P}<0.05)$, but those in experimental groups II and III were significantly decreased compared to those in the positive control $(\mathrm{P}<0.05)$. However, cortisol levels in experimental groups II and III on day 5 post-treatment did not differ significantly compared to the negative control. In the present study, the drug $(1.0 \mathrm{~kg} /$ ton feed $)$ showed a potential effect in the reduction of FMD vaccine-stress in cattle after treatment for 5 days.

The FMD vaccines that are currently used worldwide consist of only inactivated vaccines which are commonly produced with gel- or oiladjuvant depending on the serotype (LEE et al., 2016). In Korea, oil-adjuvanted vaccines against three serotypes, O (O1 Manisa), A (A Malaysia 97), and Asia 1 (Asia 1 Shamir), have continued to be

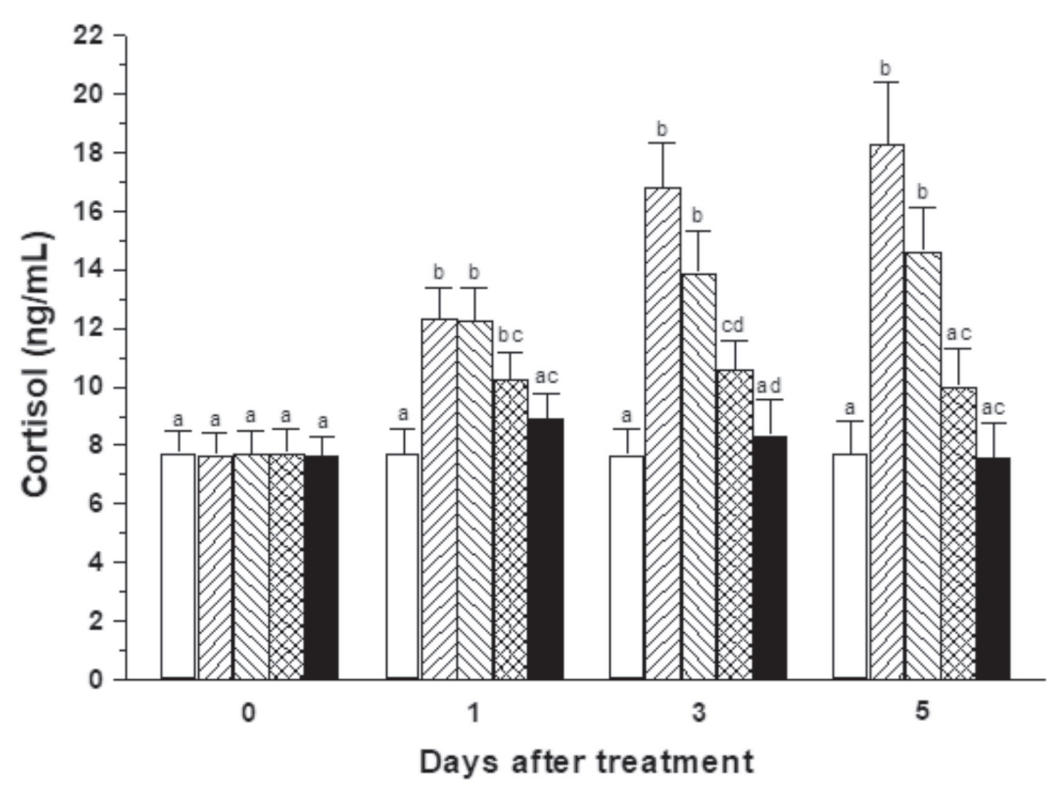

Fig. 1. Changes in cortisol concentrations in the serum of cattle after CAV administration for 5 consecutive days.

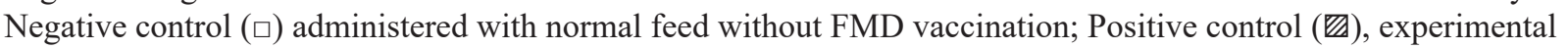

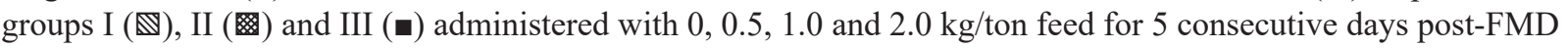
vaccination. Means within the same day after drug treatment with different superscripts are significantly different

$(\mathrm{P}<0.05)$. 
used since early 2011 (LEE et al., 2013). According to the results of a survey on animal responses after such FMD inoculation practices, stress, fever, pain, loss of appetite, lethargy, and a temporary decrease in milk production and growth rate in some cases were observed among the vaccinated animals (LEE et al., 2013). In cattle, many conditions have been considered to be stressors, such as vaccination, weaning, mixing and transportation, and have been shown to lead to increased blood concentrations of cortisol (GLYNN et al., 2013). Acetaminophen is an analgesic and antipyretic agent, and the antinociceptive effect of the drug has been reported in animal models of pain (IM et al., 2012). Considering the administered dose and blood concentration of acetaminophen in a previous study (SAWAGUCHI et al., 2016), the effective concentration for the relief of stress in the blood of treated calves is presumed to be $1.04 \mu \mathrm{g} /$ mL. EARLEY and CROWE (2002) reported that serum cortisol concentrations in calves injected with ketoprofen ( $3 \mathrm{mg} / \mathrm{kg}$ body weight (BW)) postsurgical castration were significantly decreased compared to those in surgically castrated calves $(\mathrm{P}<0.05)$. Also, a previous study by GLYNN et al. (2013) showed that serum cortisol levels in dehorned calves intravenously treated with flunixin $(2.2 \mathrm{mg} /$ $\mathrm{kg}$ b.w.) was significantly decreased compared to that in controls over 7 days post-dehorning $(\mathrm{P}<0.05)$. However, there was no significant reduction in cortisol concentrations in dehorned calves treated orally with meloxicam and gabapentin at a dose of $2.2 \mathrm{mg} / \mathrm{kg}$ b.w. On the other hand, RODRIGUES et al. (2015) reported that serum cortisol levels in beef cattle showed no significant difference between the control and a group orally administered with meloxicam ( $1 \mathrm{~kg} / \mathrm{b} . \mathrm{w}$. daily) over 7 days before and 7 days after vaccination against respiratory pathogens. Considering the dosage, route and period of administration, the CAV $(0.5$ and $1.0 \mathrm{~kg} /$ ton feed) used in this study was more efficient than meloxicam and gabapentin in reducing the stress of FMD vaccination, but less than ketoprofen and flunixin.

Changes in serum TNF- $\alpha$ concentrations are presented in Table 1.

On day 1 post-treatment, TNF- $\alpha$ concentrations were not significantly different in all drug treatment groups compared with the negative and positive controls. On day 3 post-treatment, serum TNF- $\alpha$ levels were decreased in all experimental groups compared with the positive control and were no significant differences between experimental groups II and III and the negative control. On day 5 post-treatment, serum TNF- $\alpha$ concentrations in all experimental groups were significantly decreased compared to those in the positive control $(\mathrm{P}<0.05)$, however, TNF- $\alpha$ levels in experimental groups II and III did not differ significantly to those in the negative control.

The adjuvants of FMD vaccines elicit innate immune responses associated with antigen presentation to T-cell lymphocytes, including inflammatory and acute-phase reactions (RODRIGUES et al., 2015). In a previous study by RODRIGUES et al. (2015), serum TNF- $\alpha$ concentrations in beef cattle showed no significant

Table 1. Changes in tumor necrosis factor- $\alpha$ concentrations in serum of cattle after CAV administration for 5 consecutive days

\begin{tabular}{|l|c|c|c|c|}
\hline \multirow{2}{*}{\multicolumn{1}{c|}{ Groups }} & \multicolumn{4}{|c|}{ Days after drug administration } \\
\cline { 2 - 5 } \multicolumn{1}{|c|}{} & 0 & 1 & 3 & 5 \\
\hline Negative control group & $136.11 \pm 5.23^{\mathrm{a}}$ & $135.89 \pm 4.92^{\mathrm{a}}$ & $136.02 \pm 5.14^{\mathrm{a}}$ & $135.71 \pm 4.67^{\mathrm{a}}$ \\
\hline Positive control group & $137.77 \pm 6.38^{\mathrm{a}}$ & $142.52 \pm 11.73^{\mathrm{b}}$ & $150.34 \pm 12.07^{\mathrm{b}}$ & $157.78 \pm 12.54^{\mathrm{b}}$ \\
\hline Experiment group I & $138.23 \pm 5.27^{\mathrm{a}}$ & $139.13 \pm 7.15^{\mathrm{a}, \mathrm{b}}$ & $143.41 \pm 7.16^{\mathrm{c}}$ & $146.92 \pm 8.03^{\mathrm{c}}$ \\
\hline Experiment group II & $137.67 \pm 6.09^{\mathrm{a}}$ & $138.25 \pm 6.64^{\mathrm{a}, \mathrm{b}}$ & $139.54 \pm 6.81^{\mathrm{a}}$ & $140.81 \pm 7.11^{\mathrm{a}}$ \\
\hline Experiment group III & $137.89 \pm 5.41^{\mathrm{a}}$ & $137.49 \pm 6.93^{\mathrm{a}, \mathrm{b}}$ & $137.73 \pm 6.22^{\mathrm{a}}$ & $138.14 \pm 6.59^{\mathrm{a}}$ \\
\hline
\end{tabular}

Means within the same column with different superscripts are significantly different $(\mathrm{P}<0.05)$. 
difference between the control and a group orally administered with meloxicam $(1 \mathrm{~kg} /$ body weight daily) over 7 days before and after vaccination against respiratory pathogens. Also, LEE et al. (2014) reported that TNF- $\alpha$ level was decreased in FMD vaccinated-pigs supplemented with germanium biotite $(30 \mathrm{~kg} / \mathrm{ton}$ feed) for 5 weeks, but there were no significant differences between the treatment pigs and the control. Compared with these previous studies, CAV $(1.0$ and $2.0 \mathrm{~kg} /$ ton feed) was more effective than meloxicam and germanium biotite in decreasing serum TNF- $\alpha$ levels. In this study, CAV reduced serum TNF- $\alpha$ concentrations because the vitamin $\mathrm{C}$ contained in the CAV inhibits nuclear transcription factor kappa $\mathrm{B}$, which is responsible for the activation of some pro-inflammatory cytokines, such as TNF- $\alpha$, IL1, IL6 and IL8 (TELANG, 2013).

In conclusion, the efficacy of the treatment of experimental groups II and III against stress and inflammatory responses caused by FMD vaccination was demonstrated by the alleviation of symptoms caused by FMD vaccination, with a fall in serum cortisol and TNF- $\alpha$ concentrations. The results of this study suggest that dietary supplement of the CAV at the level of $1.0 \mathrm{~kg} /$ ton feed for 5 days after FMD vaccination may be useful for the release of stress and inflammatory response to FMD vaccination.

\section{Acknowledgments}

This research was supported by Dae Han New Pharm Co. Ltd. (Seoul, Korea).

\section{References}

EARLEY, B., M. A. CROWE (2002): Effects of ketoprofen alone or in combination with local anesthesia during the castration of bull calves on plasma cortisol, immunological, and inflammatory responses. J. Anim. Sci. 80, 1044-1052. DOI: $10.2527 / 2002.8041044 x$

GLYNN,H.D.,J.F.COETZEE,L.N.EDWARDS-CALLAWAY, J. C. DOCKWEILER, K. A. ALLEN, B. LUBBERS, M. JONES, E. FRACCARO, L. L. BERGAMASCO, B. KUKANICH (2013): The pharmacokinetics and effects of meloxicam, gabapentin, and flunixin in postweaning dairy calves following dehorning with local anesthesia. J. Vet. Pharmacol. Ther. 36, 550-561.

DOI: $10.1111 /$ jvp. 12042
IM, K. S., H. J. JUNG, J. B. KIM, J. M. LEE, H. J. PARK, C. H. JOO, D. E. MOON (2012): The antinociceptive effect of acetaminophen in a rat model of neuropathic pain. Kaohsiung J. Med. Sci. 28, 251-258.

DOI: 10.1016/j.kjms.2011.11.003

JAMAL, S. M., G. J. BELSHAM (2013): Foot-and-mouth disease: past, present and future. Vet. Res. 44, 1-14.

DOI: 10.1186/1297-9716-44-116

LEE, J. A., B. G. JUNG, M. JUNG, T. H. KIM, H. S. YOO, B. J. LEE (2014): Dietary germanium biotite supplementation enhances the induction of antibody responses to foot-andmouth disease virus vaccine in pigs. J. Vet. Sci. 15, 443447.

DOI: 10.4142 jvs.2014.15.3.443

LEE, J. H., I. J. KANG, A. R. KIM, Y. S. NOH, H. C. CHUNG, B. K. PARK (2016): Increased humoral antibody response of foot-and-mouth disease virus vaccine in growing pigs pre-treated with poly- $\gamma$-glutamic acid. J. Vet. Sci. 17, 253256.

DOI: $10.4142 /$ jvs.2016.17.2.253

LEE, H. S. N. H. LEE, M. G. SEO, Y. J. KO, B. KIM, J. B. LEE, J. S. KIM, S. PARK, Y. K. SHIN (2013): Serological responses after vaccination of growing pigs with foot-andmouth disease trivalent (type $\mathrm{O}, \mathrm{A}$ and Asia1) vaccine. Vet. Microbiol. 164, 239-245.

DOI: 10.1016/j.vetmic.2013.02.012

RODRIGUES, M. C., R. F. COOKE, R. S. MARQUES, S. A. ARISPE, D. H. KEISLER, D. W. BOHNERT (2015): Effects of oral meloxicam administration to beef cattle receiving lipopolysaccharide administration or vaccination against respiratory pathogens. J. Anim. Sci. 93, 5018-5027.

DOI: $10.2527 /$ jas.2015-9424

SAWAGUCHI, A., K. SASAKI, K. MIYANAGA, M. NAKAYAMA, M. NAGASUE, M. SHIMODA (2016): Rapid absorption of diclofenac and acetaminophen after their oral administration to cattle. J. Vet. Med. Sci. 78, 1481-1485.

DOI: $10.1292 /$ jvms.16-0202

TELANG, P. S. (2013): Vitamin C in dermatology. Indian Dermatol. Online J. 4, 143-146.

YERUHAM, I., H. YADIN, M. HAYMOVICH, S. PERL (2001): Adverse reactions to FMD vaccine. Vet. Dermatol. 12, 197-201.

DOI: 10.1046/j.0959-4493.2001.00221.x 
PARK, E-K., S-E. SON, S. KIM, H-J. LEE: Učinak dodataka prehrani acetaminofena i vitamina C na stres i upalni odgovor u korejske autohtone pasmine goveda cijepljene protiv slinavke i šapa - kratko priopćenje. Vet. arhiv 89, 87-92, 2019.

\section{SAŽETAK}

U ovom se radu istražuje učinak kombinacije acetaminofena i vitamina C (CAV) na smanjenje stresa i upalnog odgovora u teladi cijepljene protiv slinavke i šapa. Ukupno 25 životinja podijeljeno je u pet skupina po pet životinja. Životinje u negativnoj kontrolnoj skupini nisu cijepljene i nisu dobile dodatke prehrani. Životinje u pozitivnoj kontrolnoj skupini i pokusnim skupinama I, II i III cijepljene su cjepivom protiv slinavke i šapa i dobile su dodatak prehrani CAV u koncentracijama od 0,0, 0,5, 1,0 i 2,0 kg/toni hrane, pet uzastopnih dana poslije cijepljenja. Peti dan nakon tretmana serumski kortizol i faktor nekroze tumora alfa (TNF- $\alpha$ ) bili su znakovito smanjeni u svim pokusnim skupinama u usporedbi s pozitivnom kontrolnom skupinom $(\mathrm{P}<0,05)$. Nije bilo znakovite razlike u vrijednostima serumskog kortizola i TNF- $\alpha$ između pokusne skupine 1 i 2 i negativne kontrolne skupine. Rezultati ovoga istraživanja upućuju na to da bi CAV mogao biti koristan u kontroli stresa i upale uzrokovane cjepivom protiv slinavke i šapa u teladi.

Ključne riječi: cjepivo protiv slinavke i šapa, serumski kortizol, serumski TNF- $\alpha$, acetaminofen, vitamin C, govedo 